Жұмажанова Ф.Т., Көптілеуова А.Т.

Аіни шығармахардағы көркемдік сабақтастық

Zhumazhanova F.T., Koptyleuova D.T.

Art continuity in religious works

Жумажанова Ф.Т., Коптилеуова А.Т.

Художественная преемственность в религиозных произведениях
Көркемдік дәстүр жалғастығы - қазақ әдебиеттану ғылымында тарихи және теориялық жағынан барлық қырынан, жан-жақты зерттеліп жатқан күрделі мәселелердің бірі болып табылады. Қазақ, әдебиетіндегі дәстүр сабақтастығының бастау көзі ежелгі әдебиет нұсқаларында жатыр, авторлар мақалада сол жәдігерлерге бірсыпыра тоқталып ашып көрсетеді. Ежелгі дәуір әдебиетінің нұсқалар, яғни сақтардың «Алып Ер Тоңға» мен «Шу», ғұндардың «Атимла», «Көк бөрі», «Ергенекон» дастандары мен "Хуастуанифтта» Көк тәңіріге табыну басым болса, ислам діні келгеннен кейінгі туған орта ғасыр мен қараханиттер дәуірінде туған жәдігерлерде А^лаға мінажат ету көрінісі басым. Мақалада мысалға келтірілген еңбектердің бәрінде де бірінші Алманың атына мақтау айтылатындығы сөз етілді. Олай болса, алғашында Көк тәңіріге, ислам дінін қабылдағаннан кейінгі күлмі мұсылман халықтарының Амланы хақ деп танығанына мақалада сөз болған тасқа түскен жазбалар мысал бола алады.

Түйін сөздер: Аін, иман, ислам, көркемдік сабақтастық, жәдігер.

In the article authors discusses the ancient literary written monuments as sources of continuity of traditions in the Kazakh literature. Analysis and comprehensive description of the discussed written monuments are given.

Key words: religion, faith, islam, literary continuity, heritage.

В статье авторы рассматривают Аревние митературные письменные памятники в качестве источников преемственности традиций в казахской митературе. Аается анализ и всесторонее описание рассматриваемых письменных памятников.

Ключевы слова: религия, вера, ислам, хужеожественная преемственность, наследие. 


\section{$\triangle \mathrm{IIHИ}$ \\ ШЫҒАРМАААРААҒЫ KӨPKEMAIK САБАҚТАСТЫҚ}

XIX ғасырдағы қазақ әдебиетінде шариғат негіздерінің көрінісі қалай суреттелгенін зерттеу барысында үңілген ғылыми зерттеулер мен әдебиеттер қатарынан ең алдымен ерекшелеп зер салуға ықпал еткені Абай еңбектері болғанмен оған дейін де шариғат тақырыбын Бұқар жырау Қалқаманұлы, Дулат Бабатайұлы, Мәделі Жүсіп қожа, Майлықожа Сұлтанқожаұлы жырлағаны ақиқат. Алайда аты аталған қазақ ақындары бастауды қайдан алды. Оларға кім, не үлгі болды деген сауалдардың төңірегінде ой қозғайтын болсақ, бұл мәселенің төркіні ежелгі әдебиет нұсқаларында жатқаны әдебиет тарихынан мәлім. Сөзіміз дәйекті болу үшін ежелгі әдебиетті зерттеушілер мен сол тұстағы мұраларға үңіліп көруге болады. Дінтанушы ғалым М. Бұлұтай түркі халықтарының бұрынғы наным-сенімдері жөнінде сөз ете келіп: «...Бір шындығы, аталмыш аймақта көптәңірлі діндердің бірте-бірте жоғалып, біртәңірлі діндерге, ең соңында хақ дін Исламға орын бергені байқалады» $[1,1]$, - деген тұжырым жасайды. Дінтанушы ғалымның осы айтқан сөзін ежелгі әдебиет нұсқаларынан мысалдар келтіре отырып өрбітуге болады. Себебі, әдебиет ақын-жазушылардың өздері өмір сүрген дәуірінің шынайы картинасы болып табылады. Ежелгі дәуір әдебиетін арнайы зерттеген ғалымдардың еңбегі туралы Т. Кәкішұлы былай дейді: «Айрықша белсене еңбек еткен Мырзатай Жолдасбеков (архон жазбалары), Мұхтар Мағауин (жыраулар поэзиясы), Асқар Егеубаев (көне жазба әдебиет), жалпылай шолу жасаған Ханғали Сүйіншәлиевтерге студенттік жәрдемін тигізіп жүрген Алма Қыраубаева сынды қарындастарымыз болды» $[2,6]$. XIII-XIV ғасыр әдебиеті жөнінде А. Қыраубаева мындай тұжырым жасайды: «Әдебиетіміздің тарихында өзіндік iз қалдырған осындай елеулі мұралардың бірі - XIII-XIV ғасырлардағы ескерткіштер. Осы кезең ескерткіштеріне тән жанрлық, тақырыптық, көркем тілдік сипаттардың ізі, өзара сабақтастық кейінгі дәуірлердегі әдебиетімізден, әсіресе XIXXX ғасыр басындағы қазақ әдебиетінен жақсы байқалады» [3, 12]. Олай болса, XIX-XX ғасыр басындағы әдебиетті сөз ету үшін сол ежелгі әдебиет нұсқаларына үңілген жөн.

«Көркемдік дәстүр жалғастығы - қазақ әдебиеттану ғылымында тарихи және теориялық жағынан барлық қыры 
толық күйінде, жан-жақты зерттеле қоймаған aca күрделі проблемалардың бірі болып табылады. Ал, бұл мәселені ғылыми тұрғыдан зерттеу - ұлттық сөз өнерінің эстетикалық қуатын, философиялық мән-мағынасын, әрбір әдеби жәдігерліктің өмірге келу себептерін айқындап алуға мүмкіндік береді» $[4,11]$, - деген ғалымдардың пікіріне сүйенетін болсақ, қазақ әдебиетіндегі дәстүр сабақтастығының бастау көзі ежелгі әдебиет нұсқаларында жатқандықтан, сол жәдігерлерге бірсыпыра тоқталуға тура келеді. Соңғы жылдары ұлттық әдебиеттану ғылымы ескі жәдігерлерге үңілу барсында көптеген жетістіктерге қол жеткізді. Соның нәтижесінде 10 томдық «Қазақ әдебиетінің тарихы» жасалды. Бұл еңбекте фольклор үлгілерінен бастап, қазіргі тәуелсіздік тұсындағы қазақ әдебиетінің даму үлгілері түгел қамтылғанын ескерсек, осы еңбектің 2-томы ежелгі дәуір және орта ғасыр әдебиетіне арналған. Мұнда ежелгі дәуір әдебиеті мен орта ғасырлардағы көне түркі жазба жәдігерлері мен қарахандықтар тұсындағы әдебиет тұтастай қамтылып зерттеу нысанына алынды. Аталған дәуір әдебиетін зерттеуші ғалымдар сақтардың қаһармандық дастандарынан «Алып Ер Тоңға» мен «Шу» дастанын, ғұндардың батырлық жырларынан «Атилла», «Көк бөрі», «Ергенекон» дастандары мен «Хуастуанифт» әдеби жәдігерлерін тыңғылықты зерттеп, ғылыми айналымға түсірді. Зерттеуде ежелгі дәуір әдебиетінің маманы Н. Келімбетов исламға дейін өмір сүрген зороастризм діні жөнінде былай дейді: «Исламға дейінгі зороастризм діні бойынша, бүкіл жанды және жансыз табиғаттың иесі - Күн болып табылады. Жер бетіндегі тіршілік атаулы аспандағы мәңгілік Күнге тәуелді. Сол себепті ежелгі түркілердің арғы ататегі саналатын сақтар таңертең Күн көкжиектен көтеріліп, шығып келе жатқанда және кешкісін батып бара жатқанда оған сыйынып, құлшылық ететін болған. Күн-Тәңірінің құрметіне жылқы малынан құрбандық шалып отырған. Мұндай әдет-ғұрыптың бәрі зороастризм дінінің негізгі кітабы - «Авестада» айтылған». Олай болса, ежелгі әдебиет нұсқаларындағы Көкке, Күнге, Айға, Отқа, Жерге, Суға табыну осы діннің өмір сүрген уақытымен тікелей байланысты болып шығады. Ғұндардың да сақтар тәрізді Көк тәңіріне, Күнге табынғанын ескеретін болсақ, Мағжан Жұмабаевтың да «Ерте күнде отты Күннен Ғұн туған, Отты Ғұннан от боп ойнап мен туғам» деуі де осыдан. «Алып Ер Тоңға» жырындағы мына жолдарға үңіліп көрелік:
Алып Ер Тоңға келеді,

Жүз мың әскер ереді.

Жүз мың жебе кереді.

Жер қайысқан қол еді.

Тәңір сүйіп жаратқан,

Әлемді өзіне қаратқан

Қаһарын жауға таратқан,

Көк тәңірінің ұлы еді.

Осы үзіндідегі Алып Ер тоңғаны тәңірінің өзі сүйіп жаратса, сол тәңірі Көк тәңірі екендігіне көзіміз жетеді. Бұл жолдар жоғарыда айтылған зороастризм дінінің жыр жолдарындағы шынайы көрінісі. Олай болса, қазақ әдебиетіндегі шариғат көріністерін сөз еткенде ежелгі әдебиет нұсқаларында жаратушы Аллаһ тағала емес, Көк, Күн, Ай, От, Жер, Су болып саналған. Қазақ арасында жаңа айды көргенде айтатын «Жаңа ай жарылқа, ескі ай есірке» деген ұғым түсініктер, отқа май құю сынды әдет-ғұрыптардың бастау көзі ежелгі дәуірлерден ұласып келе жатқандығын байқауға болады.

Ежелгі әдебиетті зерттеуші ғалымдар VI-XV ғасырлардағы нұсқалардың өзін өз ішінен үш дәуірге бөліп зерттеп жүргені мәлім. Аталған дәуірлердің бәрінен де бірнеше мысал келтіруге болады.

«Күлтегін» жырын алғаш оқыған дат ғалымы В. Томсен (1893 жылдың 23 қарашасында) «Тәңір», «Түрік» деген екі сөзді ажыратқан. Сөйтіп ұмыт болған көне мәдениет нұсқасы қайта жаңғырғанда қазақтар өздеріне етене жақын сөздермен: Тәңір, Түркі, Бек, Бай деген ұғымдармен қайта кездеседі. Бұл түркі мәдениеті мен қазақ мәдениетінің үзілмеген сабақтастығының белгісі.

Ал, жоғарыдағы мысалда келтіргендей түркілердің Көк тәңіріге жалбарынуы жөнінде ежелгі дәуір әдебиетін зерттеуші ғалым Н. Келімбетов мынадай тұжырым жасайды: «Ежелгі түріктер негізінен қос күшке - Көкке (оны Тәңірі деп те атаған) және Жерге (Жер-Суға) сыйынатын болғаны тарихтан жақсы мәлім.

Қарапайым түріктер өздерінің қағандарын сол Көк-Тәңірінің әмірімен билік жүргізіп отыр деп түсінген. Сонымен бірге, түріктер табынатын үшінші күш болған. Ол - үйдегі от басы, бала-шағаны қорғаушы әйел тәңірісі Ұмай».

XI ғасырда өмір сүрген Жүсіп Баласағұн «Кұдатғу білік» атты дастанын Қарахандар елінің қағаны Әбу Әли Хасан Сүлеймен Арыслан хан Бураханға тарту еткені мәлім.

Аллаһ және оның елшілері туралы айтылатын дастанды әдебиетші ғалым А.Егеубаев: «Жүсіп Баласағұнның «Құтадғу білік» дастаны әлем әдебиетінің асыл қазыналарының қатарындағы 
көне түркі поэзиясының өлмес мұраларының бірі», - деп бағалаған.

Ғалымдардың пікірлерінен шығатын қорытынды Жүсіп Баласағұн Кұран Кәрімді негізге ала отырып, елді бірлікке шақыра білді. Басшылардың бұқара халықты қалай басқаруы туралы ой салды. Сондықтан да негізгі төрт кейіпкердің арасындағы сұхбаттарды «Әділет», «Дәулет», «Ақыл», «Қанағат» сынды ұлы қасиеттер төңірегіне ұштастыра білді. Оның негізгі кейіпкерлері Дәулет пен Қанағат өмірден өткен соң Әділет хан мен Ақыл уәзірі екеуінің дәулет пен қанағатты іздеуіне құрылған дастан қызғылықты оқылады. Дастанның автордың елді біріктіру, көркейту, дамыту сынды үлкен арманмақсаттарынан туындағаны анық. Сондықтан да ол мемлекет деген не, оның берекесі мен бірлігі неде деген сауалдарға жауап іздеді. Білім мен біліктің, тіл мен діннің, үлкен адамгершіліктің бастауы Құран Кәрімде жатса, автордың бұл дастанда сол ізгіліктерді қалай дамыту керектігіне деген сүйіспеншілігі мен құштарлығы басым еді.

Жуырда ұлттық әдебиетіміздің қоржыны «Тәзкире-и Бұғра хан» атты мұрамен толыққаны мәлім. «Тәзкире-и Бұғра хан» - Қарахандар әулеті билеген (X-XII ғ.) кезеңдегі түрік қағанатының тарихы мен аталған мемлекеттің басты тұлғалары жайында аса құнды мәліметтер бере алатын әдеби әрі агиографиялық шығарма». Бұл шығармада Орта ғасырдағы Қашқар, Жетісу, Орта Азия аймақтарындағы Ислам діні мен мәдениетінің таралуынан да біраз мағлұматтар беріледі. Мәселен, бесінші бөлімдегі «Әзіреті Расул мен қарыздар хикаясы» былай басталады: «Бисмиллаһ-ир рахман-ир рахим!

Көне хикаялардан хабар беруші әңгімешілер мен шежірешілердің кітаптарында мынадай бір тәмсіл оқиғаны баяндайды. Күндерде [2п] бір күн Әзіреті Расул Алла Тағала (с.ғ.с) сахабаларымен таң намазын аяқтап, михрабта отыр еді. Бір пақыр кісі келіп өтініш қылды: «Иә, Алланың елшісі, екі мың алтын қарызым бар еді біреуге, берерге қаражатым жоқ. Қарыз иесі қысым көрсетіп жатыр», - деді. Расул Алланың (с.ғ.с) сарай қызметкерлері мен байлардан ешбірі тебіренбеді. Әл-қисса, [пақыр] үш мәрте арыз қылды. Әзірет Пайғамбардың (c.ғ.c) көмекшілері мен байлардан тағы да еш кісі жауап бермеді. [Сол уақытта] Әзірет Әлди (р.а.ғ.) орнынан тұрып: «Иə, Расул Алла, бұ пақырды ертіп барып, екі мың алтын қарызын мен берейін», - деп әлгі кедейді алып шықты. Үйіне ертіп келді», - деп басталады. Міне, көріп отырғанымыздай аталған мұрада пайғамбарлар туралы аңыз-әңгімелер осылайша өріліп отырады.

Сопылық поэзияның көшбасшысы Қожа Ахмет Иасауидың мұрасын зерттеуші А.Әбдірасылқызы: «Дүниежүзілік әдебиет тарихының қазына қорын молайтқан таңдаулы туындылардың елеулі бөлігі сопылық әдебиет өкілдерінің қаламына тиесілі. Сопылық таным белгілері адамзат қоғамының алғашқы дәуірінен бастап байқалып, бірқатар өркениеттер тарихында өзіндік із қалдырған. Бұл құбылыстың ішкі-сыртқы ерекшеліктері айқындалып, бірегей жүйелі үлгісі қалыптасқан кезеңі б.э.д. YІІІIX ғасырларына сәйкес келеді. Сопылық ілім теориялық тұрғыдан толық қалыптасқанға дейін-ақ оның мән-мазмұны ауызша және жазбаша әдеби шығармаларда көрініс тауып отырады. Бертінде бұл үрдіс барынша жетілдіріліп, сопылық әдебиеттің өзіне тән заңдылықтары қалыптасты. Болмысты қабылдау мен түсінудің иррационалдық жолын ұстанған сопылар тудырған әдебиеттің өзіндік идеялық бағыты, дара көркемдік әлемі, қалыптасқан бейнелілік жүйесі, талғаулы эстетикалық құндылықтары болды. Аталмыш әдебиет тарихындағы бірегей ақындық мектептер араб-парсы және түркі сопылығына тән. Ал түркі сопылық поэзиясының көшбасшысы «Түркістан пірі», «Әулиелердің сұлтаны» деген аттармен мәшһүр болған Қожа Ахмет Йасауи болатын», - дейді. Бұдан шығатын қорытынды оның сопылық поэзияның негізін салушы екендігі. Қожа Ахмет Иасауидың «Диуани хикметінен» («Ақыл кітабы») мысал келтіре отырып осы пікірлердің астарына үңіліп көрелік:

1. «Бісміллә» деп баян еттім хикмет айтып,

2. Шәкірттерге дүр мен гәуһар шаштым міне.

61. Жеті жаста Арыстан Бабқа қалдым салам,

62. Мұстапаның аманатын бер деп маған.

63. Сол мезетте мың бір зікір еттім тамам,

64. Нәпсім тыйып Аллаға бет бұрдым міне.[5, 19-20]

Хикметтен келтірілген мысалдардан көріп отырғанымыздай ҚожаАхмет Иасауи таза жолды Алланың ақ жолынан таба білген. «Ақын өзінің «Диуани хикметіне» жазған алғы сөзінде жалпы мұсылман дінінің негізгі қағида шарттарын, парыз-қарыздарын байыппен баяндайды. Мұндағы ой-тұжырымдары сегіз жүйеден тұрады. Олары: Тәубашылдық, Ғибадатшылдық, Махаббат, Сабырлық, Шүкіршілік, Ризашылдық, Заһидшілдік (анықтық), Ғаріптік. Бұларды түйіп айтсақ, адам құдайды танып білу үшін не істеу керек, қандай уәжіп, парыздарды орын- 
дау қажет дей отырып, сондай-ақ адамгершілік, әділдік, адалдық, мейірім, рақым, Аллаға деген сүйіспендік сияқты мәселелер арнайы сөз болады» $[5,12]$

Ақынның «Диуани хикметінде» негізінен Ислам дінінің қағидалары қамтылғандықтан ол үлкен беделге ие болды. Себебі Иасауидің негізгі тірегі Кұран Кәрім еді. Осы ойымызды ғалымдардың төмендегі пікірі растайды: «Ахмед Йесеуидің осыншама көп ардақталуы оның халифаларын (орынбасарлары) жан-жаққа жіберіп, тағлым-тәрбие саласында келелі қызмет істегендігінен деп ойлаймыз. Бұған қоса, Axмед Йесеуи бабамыз түркі тілін пайдаланып, түркі халықтарының Исламиятты Ұғынуында қалың бұқараға әсер еткен өсиеттер қалдырған. Осы себепке байланысты оның есімі көшпелі hәм отырықшы түркілер арасында Қорқыт ата, Шопан ата, Манас Батыр секілді мәшһүр тұлғалардың қатарында, тіпті олардан жоғары дәрежеде алатын болған. Мәселен, Хұсамаддин Шарафәддинұлы тарапынан 1584-1588 жылдары жазылған «Рисала-и Тауарих-и Бұлғария» атты еңбекте Ахмед Йесеуидің даңқының қыпшақтар һәм бұлғарлар арасында өте жоғары болғаны жазылған» $[6,83]$.

Осы ойды С.Дәуітов «Қазақ әдебиетіндегі Қожа Ахмет Иасауи дәстүрлері» атты кейінгі зерттеулерінде кеңейте зерттеді. Оның хикметтерінің мәнін ашу мақсатында астарына үңіліп ой түйді. Соның нәтижесінде: «Сопы ақын адам баласын адал еңбекке, үлкенді сыйлап, кішіні құрмет етуге, әке мен шешені, туған-туысты қадірлеуге, әсіресе, «Алланы бір, пайғамбарды хақ» деп мойындау керектігін баса айта келіп, жалпы халықты имандылыққа үндеу арқылы мұсылманшылықтың шынайы жолын нұсқайды. Әсіресе, ар тазалығы мен жан тазалығына көңіл бөледі, «малым - жанымның садағасы, жаным - арымның садағасы» деген халықтық пәлсапа тұрғысынан толғанады. Өз заманының көкейтесті мәселесі - оқу-ағарту ісін жолға қоюға, әділ билік жүргізу ісіне көп көңіл бөлді. Қожа Ахмет Иасауидің ел ішіне берік салып кеткен ислам дәстүрін бүкіл түркі елінің ақындары қабылдап, ғасырлардан ғасырларға жалғастыра жырлаған. Олардың қатарында біздің қазақ шайырларының да орны бар».

Қожа Ахметтің шығармалары жөнінде С.Дәуітов былай дейді: «Орта ғасырда ғұмыр кешкен Иасауи сол дәуірдің перзенті болғандықтан Алланы бір, пайғамбарды хақ, Құранды шын деп білген ғұлама. Ол Алланы бар жанымен жырлаған кемеңгер, жаратушының жалғыз екенін, теңдесі жоқ ұлық екенін, ешқандай мұқтажының жоқ екенін, әуелден бар, ақырында да бір өзі қалатынын шынайы толғағаны мәлім. Осындай жаны мөлдір тақуаның ел-жұрттан безіп жер астына кіруі (хлуетте жатуы) адам таң қаларлық дүние. Не үшін солай болды, кейбір деректерге қарағанда пайғамбарымыз (с.а.у.) алпыс үш жасында көз жұмды, (біздің пайғамбар жасы деп жүргеніміз - алпыс үш жас) осы себепті Қожа Ахмет Иасауи де пайғамбардан артық жасамаймын деп жер астына түсіпті делінген. Бұл мүмкін рас та шығар, Қожа Ахметке сөз берсек, ол:

Таң сәріде дүйсенбі күн жерге кірдім,

Мұстапаға қайғы тұтып кірдім, маңа.

Алпыс үште сүндет деді естіп білдім,

Мұстапаға аза тұтып кірдім, маңа -

дейді».

XII ғасырдың аяғы мен XIII ғасырдың басында өмір сүрген Ахмед Йүгінекидің тәлім-тәрбиеге құрылған «Ақиқат сыйы» атты дидактикалық еңбегінде де Алла жолы ашық көрініс берген. Адамгершілік, білім, мораль мәселелерін сөз ете отырып Алланың сөздерінен мысалдар беріледі: «Пайғамбар - оған Алланың нұры жаусын!

- Былай деген: Алла кішіпейілдінің абыройын асырады, Тәкаппардың құтын қашырады» [7, 142]. Немесе: «Алла Тағала сәлем айтқан: «Қатты ашуды басу керек, адамдардың қатесін кешіру керек», өйткені Алла игілік жасағандарды сүйеді. Алланың елшісінің оған Алланың нұры жаусын! - Айтқандарынан: «Қатты ашу келгенде оны тоқтата білген адамның жүрегін Алла қасиетке толтырады» - Алланың елшісі осылай деген [7, 143], «Алланың сәлемі мынадай: «Алла сабырлықты сүйеді, өйткені әр қасіреттің соңы қуаныш: Алланың елшісі - оған Алланың нұры жаусын! - Былай деген: «Жақсылықтан үміт етсең, сабыр ет» [7, 144], «Аллатағаланың сәлемі: «Сендегі таусылады, Алланікі мәңгібақи» [7, 145].

Ақынның мұрасын зерттеушілер оның осы дастаны жөнінде мынадай тұжырым жасайды: «Ахмет Йүгнекидің «Ақиқат сыйы» дастаны тақырыптық-мазмұндық, композициялық құрылымы жағынан ғана емес, жанрлық тұрғыдан алғанда орта ғасырдағы түркі әдебиетіне өзіндік үлес қосқан шығарма болып саналады. Дастанды жазу барысында шайыр орта ғасырда кеңінен мәлім болған қасида, қыйтға, рубаи сынды шығыстың поэзиялық жанрларын еркін пайдаланғанын талдау арқылы анықталды. Йүгнеки бір шығармада әртүрлі жанрларды 
қолдана отырып, өлең өрнегінің інжу-маржан үлгілерін жасаған. Сол арқылы ақын орта ғасырдағы түркі поэзиясының тұғырын биікке көтеруге өз үлесін қосып отыр. Бұл еңбектің авторы бірқатар жанрды қатар пайдаланып, өлең жазуды жақсы меңгерген талантты ақындардың қатарына қосылады» $[8,136]$.

«Ақиқат сыйы» поэмасында көрініп тұрғанындай, ол сыртқы құрылымының, өлшем өрнегінің жаңашылдығымен түркі өлеңінің тарихындағы бірегей туындыларының қатарына жатады.

Қорыта айтқанда, ежелгі дәуір әдебиетінің нұсқалар, яғни сақтардың «Алып Ер Тоңға» мен «Шу», ғұндардың «Атилла», «Көк бөрі», «Ергенекон» дастандары мен «Хуастуанифтта» Көк тәңіріге табыну басым болса, ислам діні келгеннен кейінгі туған орта ғасыр мен қараханиттер дәуірінде туған жәдігерлерде Аллаға мінажат ету көрінісі басым екендігіне көз жеткіздік. Жоғарыда мысалға келтірілген еңбектердің бәрінде де бірінші Алланың атына мақтау айтылатындығына көз жеткіздік. Олай болса, алғашында Көк тәңіріге, ислам дінін қаблдағаннан кейінгі күллі мұсылман халықтарының Алланы хақ деп танығанына жоғарыда сөз болған тасқа түскен жазбалар мысал бола алады. Құран аяттары мен Хадис сүрелеріне сүйене отырып ойды жинақтау, Мұхаммед пайғамбар мен басқа да пайғамбарлар туралы аңыз-әңгімелерді жырға қосу, олардың имандылық жолындағы өмірлерін өнеге ету күллі түркі халықтарының әдеби мұраларына ортақ сипат болып табылады. Бұл тұста дүниеге келген әдеби жәдігерлердің көркемдік негізгі жетістігі - Құран аяттары мен Хадис сүрелерін көркем шығармада орынды пайдалана білуі. Жоғарыда аты аталған еңбектерде баяндау, әңгімелеу, монолог, диалог, кейіпкер сөзі сынды әдіс-тәсілдерді пайдалана отырып, сол тұстағы өмір шындығын хатқа түсіру арқылы түркі халықтарының көркем шежіресі жасалды.

\section{Әдебиеттер}

1 Бұлұтай М. Ата-Баба діні? Түркілер неге мұсылман болды? - Алматы: Білім, 2000. - 504 б.

2 Кәкішев Т. Санадағы жаралар. - Алматы: Қазақстан, 1992. - 264 б.

3 Қыраубаева А. Ежелгі дәуір әдебиеті. - ХІІІ-ХІҮ ғасырлардағы түркі тілді әдебиет. - Екінші рет басылуы. - Алматы: «Алатау» баспа-полиграфиялық корпорациясы, 2006. - 168 б.

4 Қазақ әдебиетінің тарихы. Он томдық. Ежелгі дәуір және орта ғасыр әдебиеті. - Алматы: ҚазАқпарат, 2006. - 2 т. - 448 б.

5 Қожа Ахмет Иасауи. Диуани хикмет (Ақыл кітабы). Жинақты баспаға әзірлеп, қазақшаға аударғандар: М. Жармұхамедұлы, С. Дәуітұлы, М. Шафиғи. - Алматы: «Мұраттас» ғылыми-зерттеу және баспа орталығы, 1993. - 262 б.

6 Әбдірасылқызы А. Қожа Ахмет Йасауидің ақындық әлемі: монография. - Алматы: «КИЕ» лингвоелтану инновациялық орталығы, 2007. - 264 б.

7 Келімбетов Н. Ежелгі дәуір әдебиеті: хрестоматия. Екінші кітап. (Құрастырған және өмірбаяндық деректерді жазған филология ғылымының кандидаты А. Қыраубаева). - Алматы: Ана тілі, 1991. - 280 б.

8 Мырзахметов М. Абай мен Шәкәрімнің суфизмге қатысы // XXI ғасыр және Шәкәрімнің рухани мұрасы: республикалық ғылыми-теориялық конфер. материалдары - Семей: Шәкәрім атындағы Семей мемлекеттік университеті, «XXI ғасыр және Шәкәрім әлемі» ғылыми-зерттеу орталығы, 2007. - 580 б.

\section{References}

1 Bulutay. M. Ata-Baba dini? Turkyler nege musylman boldy? - Almaty: Bylym,2000.-504b

2 Kakyshev T. Sanadagy zharalar. - Almaty: Kazahstan, 1992. - 264b.

3 Kraubaeva A. Ezhelgy dauyr adebyety. - XIII-XIY gasyrdagy turkey tilde adebyet. Ekynshy basyluy. - Almaty: "Alatau" baspa polygrafyalyk korporatsiasy. $-2006 .-168 \mathrm{~b}$.

4 Kazak adebiety taryhy. On tomdyk. Ezhelgy daur zhane orta gasyr adebiety.-Almaty: Kazakparat, 2006. - 2t. - 448 b.

5 Kozhaahmet Yasauy. Diuany hykmet (Akyl kitaby) Zhinakty baspaga azirlep, kazakshaga audargandar: M. Zharmuhambeduly, C. Dautuly, M.Shafygy.-Almaty: "Murattas" Gylymy- zertteu zhane baspa ortalygy. - 1993. - 262b.

6 Abdirasylkyzy A. Kozha Ahmet yasauidyn akyndyk alemy. Monografya. -Almaty 'Kie" lingvaeltanu inovatsiyalyk ortalygy. 2007. $-264 b$.

7 Kelymbetyov N. Ezhelgy daur adebiety. Hrestomatya. Ekynshy kitab (Kurastyrgan zhane omyrbayandyk derekterdy zhazgan f.g.k. A. Kraubaeva).- Almaty: Ana tyly,1991.-280b.

8 Myrzahmetov M. Abay men Shakarymnyn sufizymge katysy // XXI gasyr zhane Shakarymnin ruhany murasy: respublikalyk gylymi teorialyk konfer. Materialdary,- Semey: Shakarym atyndagy Semey memlekettyk unybersitety, "XXI gasyr zhane Shakarym alemy" gylymi ortalygy. -2007 . -580 b. 